\title{
DESAIN KEMASAN “TAHU ROBI” DI DESA PURWODADI KECAMATAN TANJUNG BINTANG LAMPUNG SELATAN
}

\author{
Putri Endah Suwarni, Gilar Anjar Prambudi \\ Program Studi Teknik Industri Fakultas Teknik \\ Universitas Tulang Bawang Lampung
}

\begin{abstract}
The attractiveness of a package can not be separated from the target market for which the package is intended. Packaging not only carries the identity of a product, but furthermore, it reflects the image of the producer in supporting consumer satisfaction. Packaging is also an important factor when a product is about to move targets or raise segments from the lower middle segment to the upper middle segment. The packaging design activities carried out by the tofu factory are the shape, material, color, symbol / brand / logo, picture / illustration, and drawing language, the layout has the aim to introduce tofu products to the public and increase purchases.

The purpose of this research is to develop a different form of packaging with other forms of tofu packaging.

The results of the new packaging design can be found several differences from the old packaging in terms of: a more attractive form of packaging, a packaging model with a size of 250 grams, there is a new logo that has features, illustrations and visualization designed more attractive by displaying the name of the business owner.
\end{abstract}

Keywords : Design, Packaging, Consumer, Logo, Attractive

\section{Pendahuluan}

Tahu merupakan salah satu kebutuhan konsumsi bagi masyarakat khususnya di desa palputih dalam, sehingga banyak masyarakat yang tertarik untuk mengembangkan usaha rumahan. Kemasan adalah bagian yang sangat penting dalam sebuah usaha produk, tak terkecuali makanan. Kemasan juga secara langsung ikut mempromosikan produk kepada konsumennya. Suatu kemasan sangat berpengaruh terhadap sugesti dan keputusan konsumen dalam membeli suatu produk atau tidak. Secara garis besar kemasan berfungsi untuk melindungi isi dari kemasan yaitu berupa tahu, memberi kesan indah pada kemasan tahu tersebut, menambah daya jual, sekaligus mempromosikan produk secara langsung pada konsumennya. Jadi, dilihat dari fungsinya dapat diketahui bahwa betapa pentingnya suatu kemasan bagi Industri makanan termasuk tahu.

Di Desa Purwodadi terdapat banyak yang menjual berbagai macam olahan tahu ini salah satunya 
"Tahu Robi". "Tahu Robi" mempunyai pangsa pasar yang besar tetapi perusahaan ini tidak memiliki logo yang paten dan kemasan yang mendukung. Perlu dibuat perancangan kemasan produk "Tahu Robi” sebagai solusi untuk menjawab permasalahan yang ada. Mengingat usaha ini adalah usaha menengah kebawah namun digemari dari berbagai kalangan.

Pada dasarnya desain kemasan tahu dari dulu sampai

\section{Tinjauan Pustaka}

\section{Pengertian Kemasan (Packaging)}

Kotler dan Amstrong (2012) mendefinisikan "packaging involves designing and producing the container or wrapper for a product"yang artinya adalah proses kemasan melibatkan kegiatan mendesain dan memproduksi. Fungsi utama dari kemasan sendiri yaitu untuk melindungi produk agar produk tetap terjaga kualitasnya.

Kemasan mempunyai tujuan dan fungsi dalam pembuatan produk, yaitu:

a. Memperindah produk dengan kemasan yang sesuai kategori produk.

b. Memberikan keamanan produk agar tidak rusak saat dipajang ditoko.

c. Memberikan keamanan produk pada saat pendistribusian produk.

d. Memberikan informasi pada konsumen tentang produk itu sendiri dalam bentukpelabelan.

e. Merupakan hasil desain produk yang menunjukan produk tersebut.

Kemasan yang baik dapat membangun ekuitas merek dan mendorong penjualan. Beberapa

Menurut Nillson \& Ostrom (2005) dalam Cahyorini \& Rusfian sekarang tidak mengalami perubahan yang signifikan, maka dari itu butuh suatu konsep untuk mengubah kemasan tahu menjadi lebih menarik dan mudah di promosikan ke konsumen. Tujuan dari penelitian ini adalah mengembangkan bentuk kemasan berbeda dengan bentuk kemasan tahu yang lain.

(2011), variabel desain kemasan terdiri dari 3 dimensi, yaitu: desain grafis, strukturdesain, dan informasi produk.

\section{Fungsi Kemasan}

Sebuah kemasan mempunyai dua fungsi penting antara lain:

1. Kemasan harus mempunyai kegunaan fungsional bagi konsumen dan bagi perantara pada saluran distribusi. Kemasan tersebut harus melindungi produk, mencegah kerusakan, dan memperpanjang hidup produk.

2. Kemasan harus memudahkan komunikasi promosi dengan memberikan identifikasi merek yang jelas, mempromosikan produk, dan membantu menjual produk.

\section{Pentingnya Kemasan dalam Pemasaran}

Kemasan merupakan kegiatan yang berorientasi pada produksi dan dilakukan khusus untuk memperoleh manfaat perlindungan dan kemudahan. Selama beberapa tahun terakhir ini, peranan kemasan dalam pemasaran semakin meningkat dan mulai diakui sebagai suatu kekuatan utama dalam persaingan pasar. Makin meluasnya penerapan penjualan swalayan dan penjualan melalui mesin ortomatis berarti bahwa kemasan mengambil alih tugas penjualan pada saat jualbeli terjadi. Keamanan kemasan juga 
menjadi isu yang makin penting dalam pemasaran. Perkembangan baru dalam kemasan terjadi dengan cepat sekali dan tiada henti-hentinya memaksa pihak manajemen untuk terus untuk memperhatikan pembaharuan dalam desain kemasan mereka. Hasilnya dapat kita saksikan misalnya, bahan baru menggantikan bahan lama, bentuk dan ukuran yang semakin menarik, dan ciri-ciri lain Model kemasan dengan ukuran isi. Semuanya dilakukan demi kenyamanan konsumen dan juga merupakan bahan tambahan yang membantu penjualan.

\section{Prinsip-Prinsip Desain Kemasan}

Dalam desain kemasan, prinsip dasar desain disesuaikan untuk memenuhi tujuan setiap tugastugas desain. Panduan ini membantu mendefinisikan bagaimana warna, tipografi, struktur, dan citra diaplikasikan dalam suatu tata letak desain untuk menciptakan kesan keseimbangan, intensitas, proporsi, dan penampilan yang tepat.

Berikut adalah faktor-faktor yang mempengaruhi desain kemasan produk.

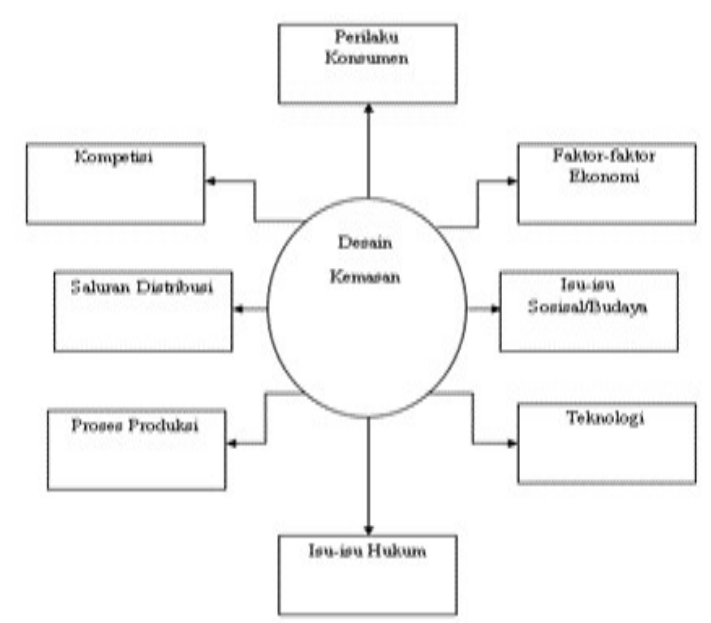

Gambar 1. Faktor-faktor yang mempengaruhi Desain Kemasan

\section{Struktur Desain}

Struktur desain berkaitan dengan terdiri dari

fitur-fitur fisik kemasan, dan

3 sub-dimensi: bentuk, ukuran, dan material.

\section{Bentuk}

Bentuk mempengaruhi proteksi dan fungsi keamanan dalam menyentuh, menuangkan, menyimpan dan menyatakan bahwa bentuk yang lebih sederhana lebih menarik dari pada yang biasanya, dan persegi panjang lebih banyak disukai dari pada kotak.

2. Ukuran

Ukuran adalah measurement yaitu cara menilai jumlah objek, waktu, atau situasi sesuai dengan aturan tertentu.

3. Material

Sejarah penggunaan bahan kemasan sudah berlangsung dengan sangat lama. Bahan kemasan pada mulanya menggunakan daun, kulit hewan, produk pecah belah, dan tas. Bahan kemasan mempengaruhi persepsi konsumen terhadap kualitas produk. Sedangkan bahan kemasan dapat membangkitkan emosi dan perasaan tertentu, biasanya tanpa orang tersebut menyadarinya.

\section{Informasi Produk}

Salah satu fungsi kemasan adalah untuk mengkomunikasikan produk melalui Informasi yang tertera. Informasi produk dapat membantu konsumen dalam mengambil keputusan pembelian dengan lebih hati-hati. Berdasarkan uraian diatas, maka dapat dikatakan bahwa kemasan memiliki peranan cukup penting bagi suatu produk. Selain befungsi sebagai pelindung produk, kemasan juga secara tidak langsung menggambarkan jati diri produk itu sendiri. Dimensi-dimensi dari kemasan memiliki peran masingmasing untuk menghasilkan kemasan yang baik dan menarik, karena semakin menarik kemasan tersebut semakin menarik perhatian para konsumen. 


\section{Metodologi Penelitian}

\section{Lokasi Penelitian}

Penelitian ini dilaksanakan pada IKM tahu yang beralamat di Desa Purwodadi Dalam Kecamatan Tanjung Bintang Kabupaten Lampung Selatan.

\section{Sumber Data dan Pengumpulan} Data

Berdasarkan sumber data yang digunakan dalam penelitian ini adalah data primer dan data skunder. Data primer ialah data yang diperoleh secara langsung dari perusahaan berupa hasil pengamatan setempat dan dokumen perusahaan serta wawancara langsungpada pimpinan perusahaan maupun pada karyawan perusahaan yang bersangkutan. Sedangkan data skunder adalah data yang tidak langsung diperoleh dengan proses membaca, penelitian dahulu serta mempelajari dan mengambil keterangan yang diperlukan dalam buku.

\section{Metode Design}

Desain bisa diterjemahkan sebagai seni terapan, arsitektur, dan berbagai pencapaian kreatif lainnya. Proses desain pada umumnya memperhitungkan aspek fungsi, estetika, dan berbagai macam aspek lainnya dengan sumber data yang didapatkan dari riset, pemikiran, brainstorming, maupun dari desain yang sudah ada sebelumnya. Akhirakhir ini, proses secara umum juga dianggap sebagai produk dari desain, sehingga muncul istilah "perancangan proses". Salah satu contoh dari perancangan proses adalah perancangan proses dalam mendesain sebuah kemasan produk tahu.

Dalam metode design ini peneliti menggunakan metode Managing yaitu merupakan metode dengan cara menciptakan desain secara berkelanjutan dan terus-menerus.

\section{Alur Penelitian}

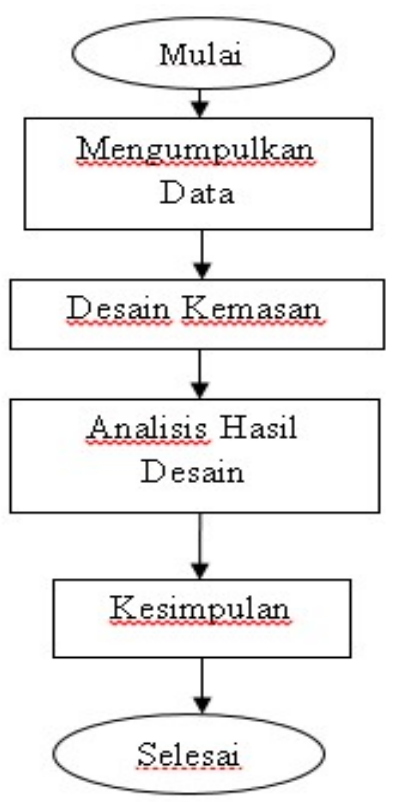

Gambar 2. Diagram Alur Penelitian

\section{Konsep Perancangan}

\section{Logo Type}

Logo berfungsi sebagai tanda atau ciri/pembeda suatu perusahaan atau dapat digunakan untuk sarana informasi, membangun citra/image positif di mata publik. Logo yang baik mempunyai beberapa karakteristik diantaranya adalah logo harus mempunyai nilai keterbacaan tinggi meskipun diaplikasikan dalam berbagai ukuran dan media yang berbeda-beda, sederhana, mudah ditangkap dan dimengerti dalam waktu singkat, mudah diingat, mudah diasosiasikan dengan jenis usaha dan citra perusahaan, aplikasi 
logo yang baik dari warna, bentuk, konfigurasi logo pada beberapa media grafis.

Logo dari IKM "Tahu Robi" awalnya tidak memiliki logo atau karakteristik tersendiri. Logo ini pun dirancang agar masyarakat mudah mengingat "Tahu Robi".

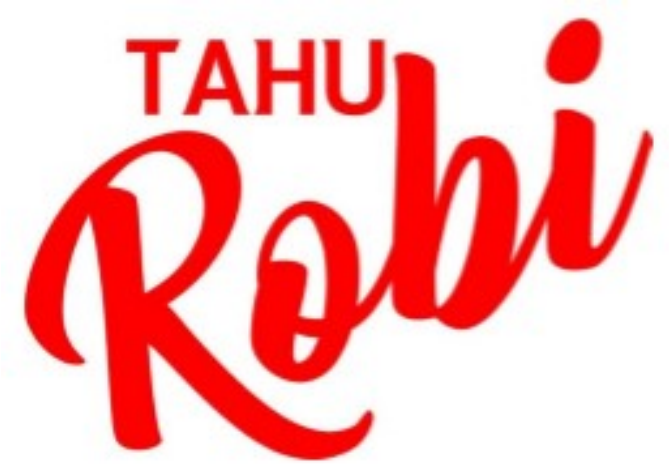

Gambar 3. Logo Tahu Robi

Logo "Robi" ini menggunakan font Bernadette. Warna yang dipilih pun merupakan warna merah yang melambangkan kuat dan berani yang menggambarkan tidak takut bersaing dengan usaha sejenisnya

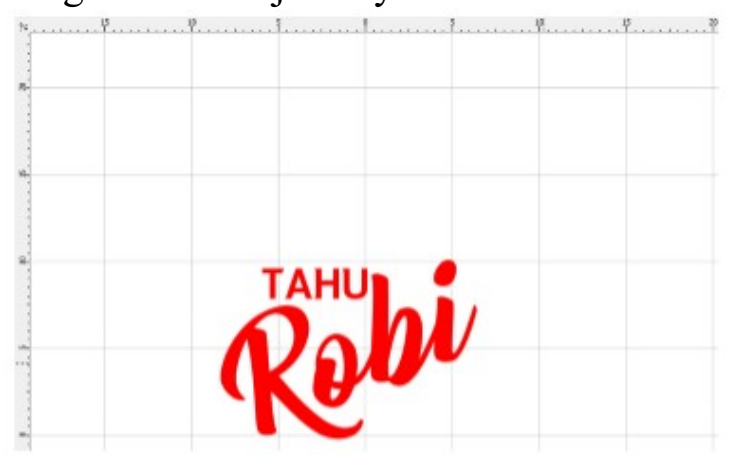

Gambar 4. Grid / Kisi

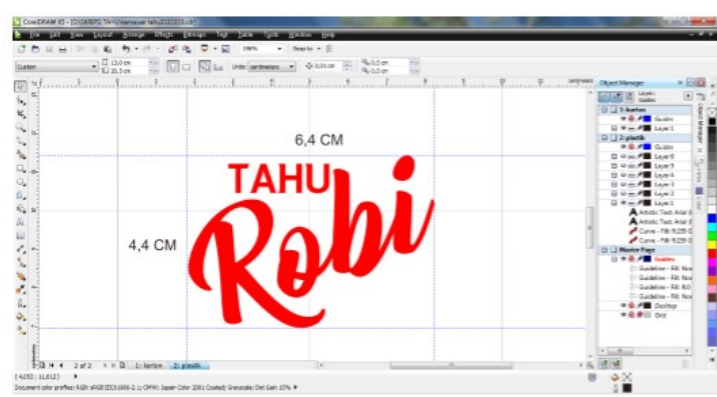

Gambar 5. Ukuran Logo

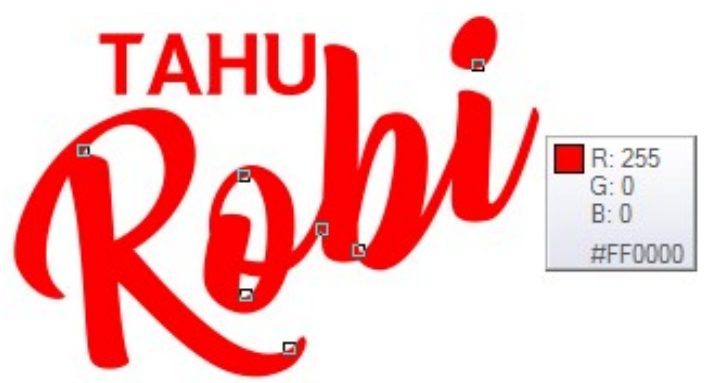

Gambar 6. Warna Logo

\section{Bentuk}

Bentuk kemasan merupakan pendukung utama yang membentuk daya tarik visual. Bentuk kemasan ditentukan oleh beberapa aspek, seperti sifat produk, pertimbangan mekanis, kondisi penjualan dan pertimbangan pemajangan/display. Beberapa pertimbangan bentuk dalam kemasan antara lain: bentuk yang sederhana lebih disukai, bentuk yang teratur mempunyai daya tarik lebih dan bentuk harus seimbang.

Bahan

Bahan dengan perkembangan di bidang industri kemasan, bahan/material kemasan sangat beragam. Dalam desain kemasan ini menggunakan bahan dari plastik agar makanan atau jajanan menjadi awet dan tidak rusak.

\section{Ilustrasi}

Ilustrasi mempunyai beberapa fungsi antara lain : menarik perhatian, menonjolkan salah satu keistimewaan produk, memenangkan persaingan dalam menarik perhatian konsumen, mendramatisasi pesan, menjelaskan suatu pernyataan, menciptakan suasana khas dan menonjolkan suatu merek atau menunjang slogan yang akan ditampilkan. Dalam pembuatan kemasan, warna merupakan hal sangat penting dan harus dipertimbangkan dengan matang. Warna yang salah pada kemasan akan membuat target market kurang tertarik pada produk. 


\section{Warna}

Dalam pembuatan kemasan, warna merupakan hal sangat penting dan harus dipertimbangkan dengan matang. Warna yang salah pada kemasan akan membuat target market kurang tertarik pada produk. Fungsi dari warna diantaranya untuk identifikasi, untuk menarik perhatian, menimbulkan pengaruh psikologis, mengembangkan asosiasi terhadap produk, menciptakan suatu citra dan membangkitkan minat. Warna yang digunakan dalam pembuatan kemasan "Tahu Robi" menggunakan warna merah dan kuning. Warna yang dipilih tersebut melalui pertimbangan khusus sesuai dengan fungsi warna itu sendiri serta pertimbangan dari segi targer market.

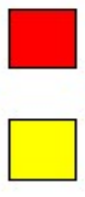

$=\mathrm{R}: 255 \mathrm{G}: 0 \mathrm{~B}: 0$

$$
=\mathrm{R}: 255 \mathrm{G}: 255 \mathrm{~B}: 0
$$

Tipografi

Tipografi adalah seni menyusun huruf. Tipografi erat kaitannya dengan font, typeface dan rypefamily. Font adalah satu set huruf yang berukuran sama dan mempunyai style yang sama. Font terdiri dari satu set huruf A sampai $\mathrm{Z}$, angka dan tanda-tanda. Typeface adalah satu set dari alphabetical dan numerical karakter yang mempunyai style dan karakteristik dominan yang sama. Sedangkan typefamily adalah satu set type lengkap dengan variannya dari sebuah typeface, termasuk roman, italic, expanded, condensed dan sebagainya.

Berikut salah satu contoh font Harlow Solid Italic:

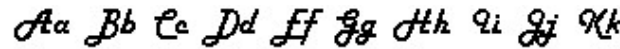

$f^{l} d_{m} d_{n}$ to $\delta_{p} Q_{q} d_{z} \delta_{s} \delta_{t} Q_{u}$

$\mathcal{V}_{r}$ Ww $_{w} \mathscr{x}_{x} \mathscr{g}_{y} z^{2}$

\section{0}

\section{Perancangan Kemasan}

Dalam perancangan kemasan produk "Tahu Robi" ini tehnik pelaksanaan pekerjaan gambar dari awal hingga selesai adalah sebagai berikut:

1. Sket kasar / rough menggambar dengan sket kasar terlebih dahulu untuk mempermudah dalam perancangan bentuk kemasan dan menghindari terlalu banyak dalam menghapus kesalahan. Sket kasar biasanya diawali dengan bentuk kemasan yang sederhana terlebih dahulu. Setelah menemukan ide kreatif, barulah dibuat sket kemasan sesuai dengan ide yang didapat.

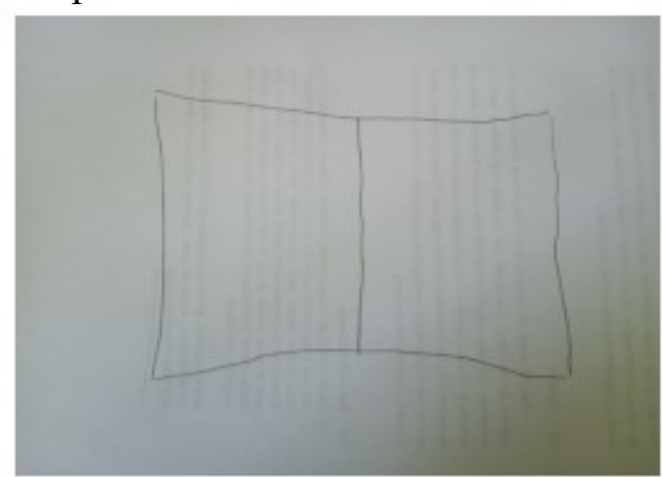

Gambar 7. Sketsa Dasar

\section{Sket komprehensif}

Setelah mendapatkan sket desain kemasan yang disetujui dan diberi ilustrasi, setelah itu gambar sket yang sudah jadi tadi diberi warna dengan pensil warna atau spidol. 


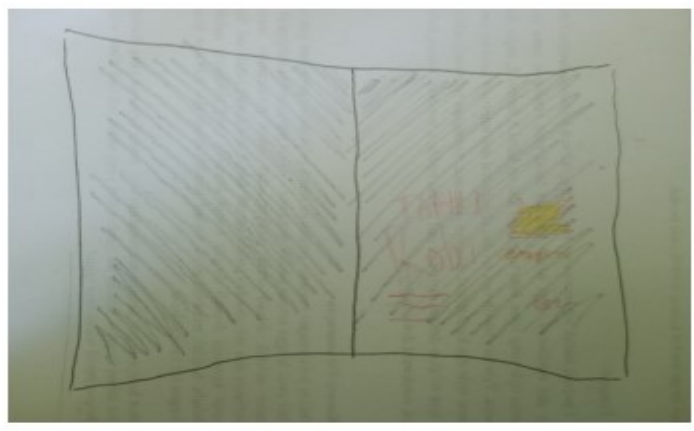

Gambar 8. Sketsa yang telah diberikan warna dengan pensil warna

\section{Perancangan dengan komputer}

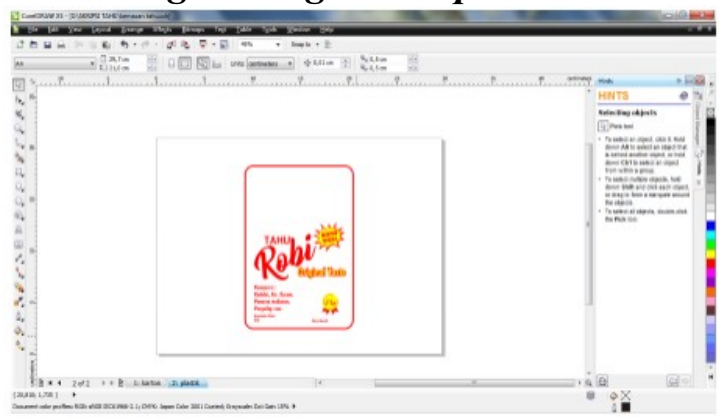

Gambar 9. Perancangan dengan komputer

\section{Pemilihan Jenis Font}

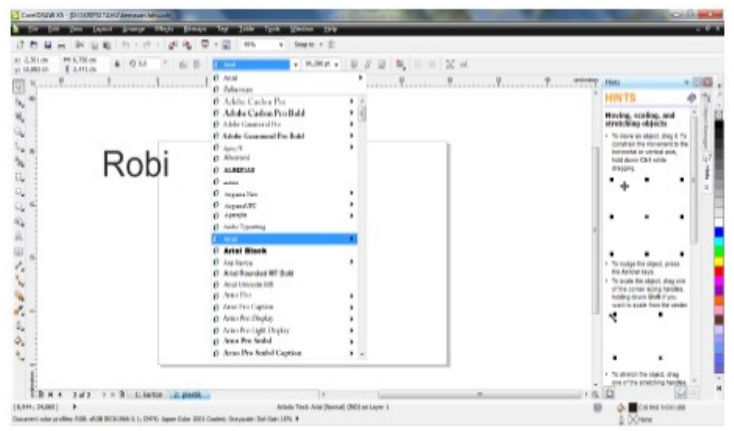

Gambar 10. Pemilihan Jenis Font

\section{Pemberian warna}

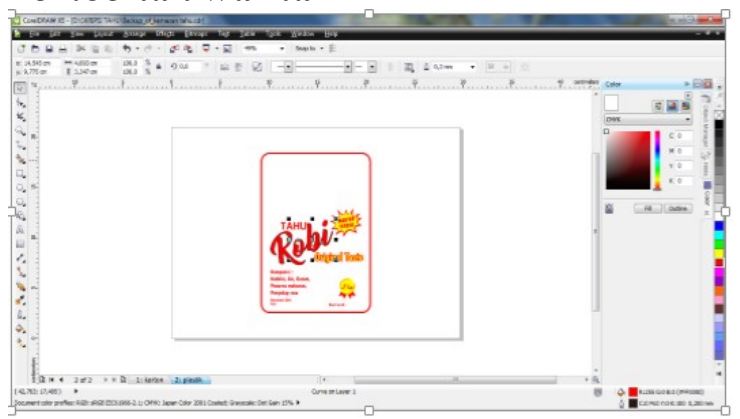

Gambar 11. Pemberian Warna

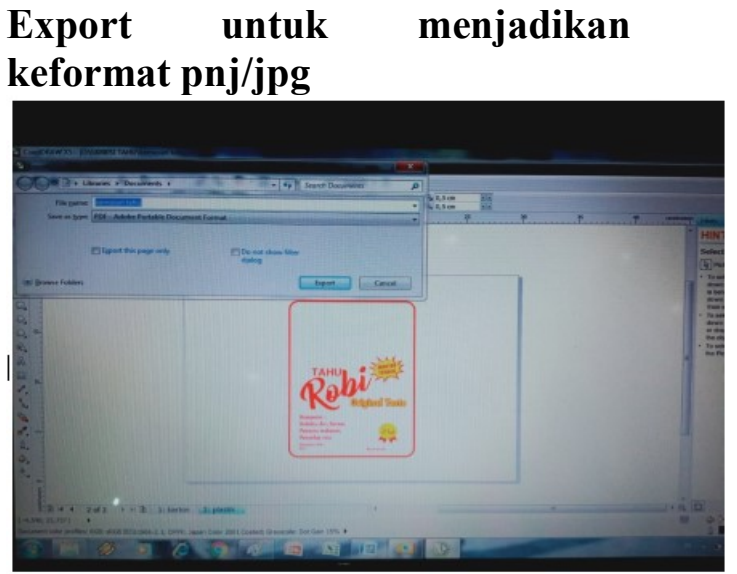

Gambar 12. Export untuk menjadikan keformat pnj/jpg

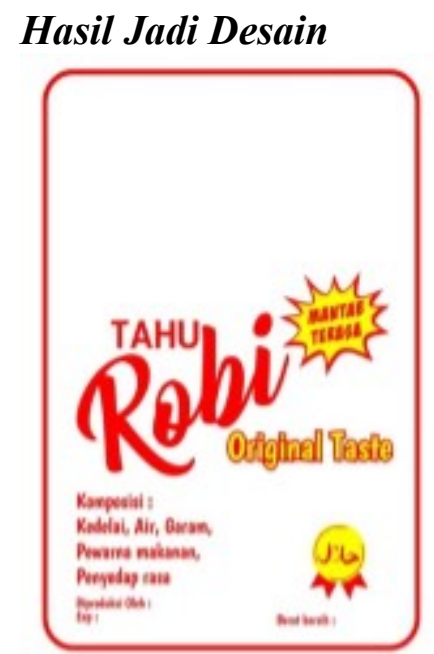

Gambar 13. Hasil Jadi Desain

\section{Teknik Pelaksanaan}

Untuk membuat sebuah kemasan perlu diketahui teknik perancangan pembuatannya, untuk kemasan produk tahu robi teknik perancangannya adalah :

1. Menentukan jenis kemasan Kemasan yang akan digunakan dalam pembuatan desain yaitu dari plastik fleksibel yang berukuran 250gram.

2. Membuat Desain Kemasan Pertama kali membuat sket dasar terlebih dahulu, kemudian dikembangkan sesuai ide yang didapat. Setelah desain manual jadi, detail dibuat dengan menggunakan komputer dan juga menentukan ukuran kemasan yang diinginkan. 
3. Membuat ilustrasi pada kemasan

Untuk ilustrasi terdapat logo, gambar tahu, label halal.

4. Membuat hasil jadi kemasan Setelah semua desain kemasan dan ilustrasi selesai dibuat, kemudian masuk dalam proses pencetakan.

\section{Hasil Akhir (Karya Jadi)}

Kemasan Tahu Pong

Rencana Data Teknis :

Media / Bahan : Plastik Polypropylene (PP) 250 gr

Ukuran

Ilustrasi : $13 \mathrm{~cm}$ x $20,5 \mathrm{~cm}$

Software

: Logotype Tahu Robi, makanan

Teknik

Typography
Proses pertama desain ilustrasi dicetak, setelah itu ditempel pada lembaran karton tebal, lalu dipotong dengan pisau potong sesuai pola kemasannya.

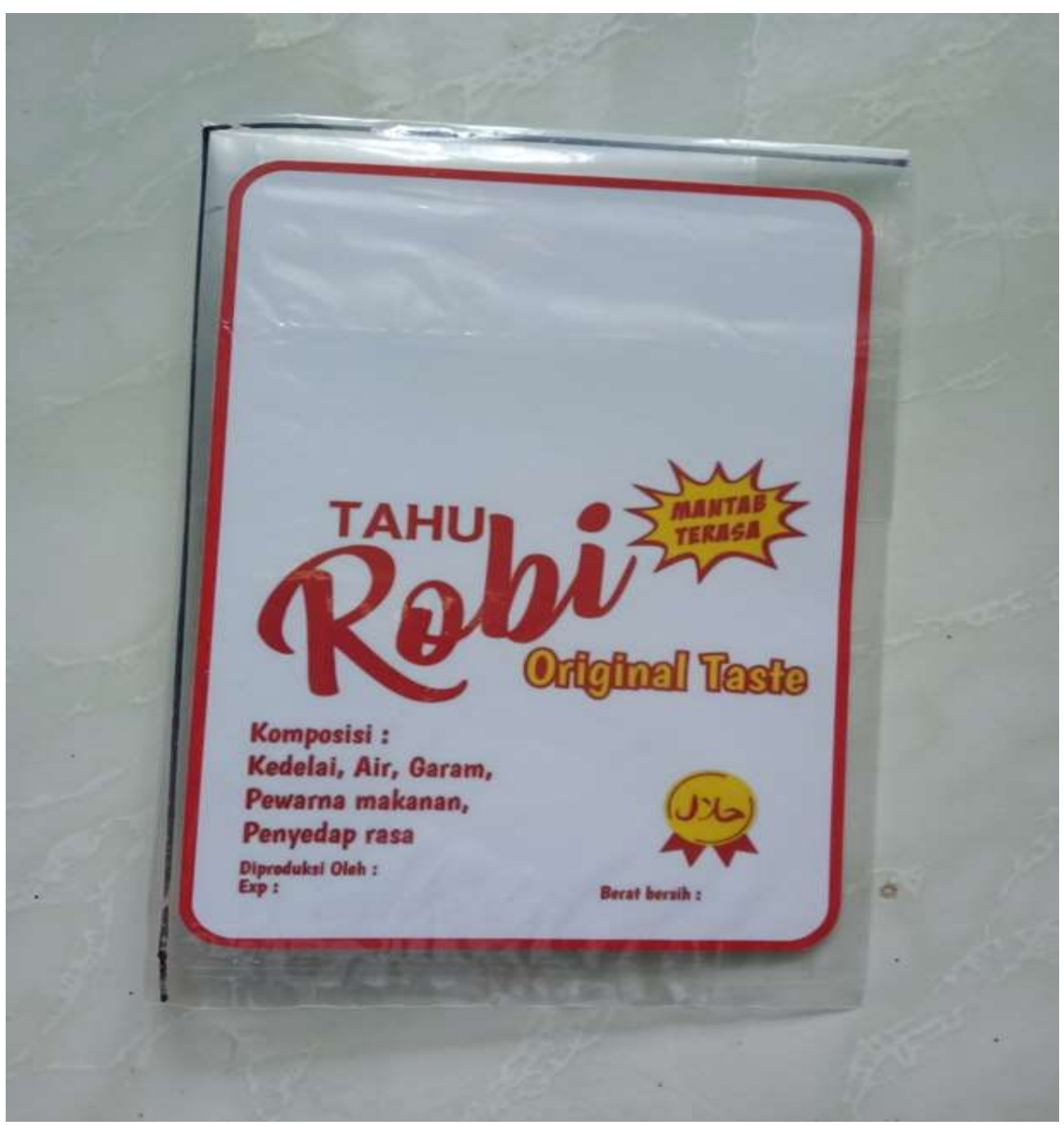

Gambar 14. Hasil Akhir

Keterangan:

Kemasan tahu ini menggunakan bahan Plastik Polypropylene 250gram dengan ukuran 
jadi $13 \mathrm{~cm}$ x 20,5 cm. Bentuk kemasan ini hanya kotak memanjang tetapi cara menutupnya dengan dipres agar kemasan ini tertutup rapat. Ilustrasi yang terdapat pada kemasan adalah logo, komposisi, rasa.

\section{Harga Sablon Plastik}

Minimal sablon manual 2.000 lembar dan untuk printing order 100.000 lembar. Untuk printing hasil maximal dan harga pasti lebih murah, apabila kurang dari 100.000 lembar maka harga sablon plastik dikenakan ongkos cetak dan biaya warna saja:

Ongkos cetak manual minimal 2000 lembar Rp.60 dan untuk plastik yang digunakan berukuran 17 x $33 \mathrm{~cm}$. Bila ukuran tulisan/gambar setengah folio/A4 $(21,5 \times 16,5) \mathrm{cm}$ maka biaya sablon:

1. Ongkos cetak

$$
=\text { Rp. } 60
$$

\section{Kesimpulan}

- Perancangan kemasan produk "Tahu Robi" sebagai solusi untuk menjawab permasalahan yang ada. Mengingat usaha ini adalah usaha menengah kebawah namun digemari dari berbagai kalangan.

- Bahan yang digunakan dalam kemasan menggunakan bahan yang mudah terjangkau, ramah lingkungan dan mudah didapat.

- Kesan yang dapat ditonjolkan pada rancangan kemasan yang baru ini adalah modern, eksklusif dan elegan serta selain sebagai promosi perusahaan.

- Dalam perancangan kemasan ini, dapat ditemukan beberapa perbedaan dari kemasan lama dengan kemasan yang baru, sebagai berikut :

\section{Kemasan lama}

a. Bentuk kemasan sama dengan kemasan tahu pada umumnya.

b. Bahan kemasan hanya menggunakan kantung plastik biasa.

c. Tidak terdapat logo yang paten.

d. Tidak terdapat ilustrasi yang menarik konsumen.
2. Biaya sablon

$=$ Rp.200/warna

3. Biaya film

$=$ Rp.100.000,-

4. Biaya cetak minimal Rp.200x2000 lembar $=$ Rp.400.000,-

\section{Kemasan baru}

a. Bentuk kemasan meskipun kotak namun sekarang lebih menarik.

b. mempunyai model kemasan dengan ukuran kemasan 250 gram.

c. Terdapat logo baru yang mempunyai ciri.

d. Ilustrasi dan visualisasi didesain lebih menarik dengan menampilkan nama pemilik usaha.

\section{Daftar Pustaka}

Cenadi, Christine Suharto. (1999). Peranan desain kemasan

dalam dunia pemasaran

Cahyorini, (2011). The Effect of Packaging Design on Impulsive Buying.Journal

Of Administrative Science \& Organization, Vol : 18, No. 1.

Cahyorini, A., \& Rusfian, E. Z. (2012). The effect of packaging design on impulsive buying. Bisnis \& Birokrasi Journal, 18(1).

Danger, Erik P. (1992). Selecting 
colour for packaging.

England: GowerTechnical

Press Ltd.

Hermawan Kartajaya. (1996) Fungsi

Kemasan

Intan, Anni. (2010). Kemasan

Produk. Medan: Universitas

Sumatra Utara.

Kustiana, Ani. (2004). Redesain

$\begin{array}{ll}\text { Kemasan } & \text { Oleh-oleh } \\ \text { Bandung. } & \text { Bandung: } \\ \text { Universitas } & \text { Komputer } \\ \text { Indonesia. } & \end{array}$

Klimchuck and Krasovec. (2007)

Prinsip Dasar Desain

Kemasan

Klimchuk, Marrianne Rosner and

Krasovec Sandra A. (2007).

Desain Kemasan,Erlangga.

Jakarta.

Lisnawati, Tri. (2011). Perancangan

Desain Kemasan Tahu

Tauhid. Bandung:

Universitas Komputer

Indonesia.

Listyawati, Indri Hastuti. (2016).

Peran Penting Promosi Dan

Desain Produk Dalam

Membangun Minat Beli

Konsumen. Jurnal Akademi

Menajemen Administrasi

Ypk, Volume 134, Nomor 1.

Renate, D. (2012). Pengemasan

Puree Cabe Merah dengan

Berbagai Jenis Plastik yang

Dikemas Vakum. Jurnal

Teknologi \& Industri Hasil

Pertanian, 14(1), 80-89.

Rosner, Mariane. (2007). Desain

Kemasan, Perencanaan

Merek Produk yang Berhasil,

Mulai dari Konsep

sampaiPenjualan. Jakarta:

Penerbit Erlangga

Suharto Cenadi, Christin, Peran

Desain Kemasan dalam

Dunia Pemasaran, Jurnal Nirmana Vol. 2 - No. 1, Januari (2000), Universitas Kristen Petra Surabaya.
Usfunia. (2017). Pengaruh Produk,

Harga, Personal dan Bukti

Fisik Terhadap Kepuasan

Pelanggan. Jurnal Ilmu dan

Riset Manajemen Volume 6

Nomor 5.

Wirya, Iwan. (1999). Kemasan yang

Menjual. Jakarta, PT.

Gramedia Pustaka Utama.

Wiyancoko, Dudy. (2007).

Desain Kemasan

Menentukan Nilai Produk,

Makalah Klinik Kemasan,

Departemen Perdagangan

Republik Indonesia 